\title{
Hazard Identification of Methanol Fuel System on Ship
}

\author{
I Made Ariana ${ }^{1, a}$, Gusma Hamdana Putra ${ }^{\text {b }}$, and Thariq Arafatul Akbar, \\ ${ }^{1}$ Department of Marine Engineering, Institut Teknologi Sepuluh Nopember,Surabaya, Indonesia \\ a.ariana_made@yahoo.com,b.putragusmahamdana@yahoo.com,c.thariqakb@gmail.com
}

Keywords: Hazard Potency, Methanol, Fuel System, Ship

\begin{abstract}
Today, dual fuel diesel engine (DF-DE) on board ship is proven to produce smaller gas emission. The most common configuration for DF-DE is by using natural gases as main fuel but does not rule out the potential of other alternative fuel such as methanol. Methanol has potential application on board as low carbon, sulphur, NOX and particulate matter. Furthermore, it can produce with natural gas and biomass that has smaller emission from a life-cycle perspective. However, Methanol which classified as low flash point fuels (LFL), it has adverse effects including toxic, volatile and corrosive. This paper will specifically identify the potential hazard of methanol fuel system on board. Even though the further proposed design of Methanol fuel system is still not fully intact, the preliminary design is already developed and can be determined as a basis for hazard potency identification. The method for this identification is Hazard and Operability (HAZOP) which refers to BS IEC 61882:2001. With an expectation that the outcome from this identification can become the recommendation for further more detailed proposed a design for methanol fuel system.
\end{abstract}

\section{Introduction}

Greenhouse gases (GHGs) are still the main reason for the regulation getting tightened. Ships that belong to one of these transportation modes have a major influence on emission gas. Based on reports from [1], total shipping gas emissions from 2013 to 2015 has increased by $+2.5 \%$, from 291 million tonnes to 298 million tonnes. With that premise, in the recent years already emerged the urgencies for marine transportation sector to lower its emission.

This issue has been responded by IMO by establishing several regulations and strategies to reduce emission gas. The regulations are EEDI, DCS, and SEEMP. The strategies include limiting ship speeds, new marine propulsion technologies, and the implementation of Annex VI, about lowe carbon fuels [2]. IMO also introduced ECAs, an area that became the object of emissions reduction, and SECA that became the object of sulphur emission reduction. [3].

Methanol, one of the alternative fuels that have low sulphur content. This fuel is produced from several basic materials such as coal, lignite, shale gas, natural gas, oil residue (vacuum residues), renewable resources such as wood and agricultural residues. Methanol that produced from natural gas is classified in low flashpoint fuel [4]. There are also several methods for producing methanol. However, the most commonly used is the Steam Reforming methods [5]. Fuels with low sulphur and carbon characteristics, the reference to compare emission levels is $\mathrm{CO} 2$ in terms of their life-cycles. Although in the production of $\mathrm{NO}_{\mathrm{x}}$ and $\mathrm{SO}_{\mathrm{X}}$ is relatively low when compared to conventional fuels, but the $\mathrm{CO} 2$ production is slightly higher [4]. 
The application of methanol fuel on the vessel has been proven by the development of dual fuel diesel engine that is diesel-methanol (DMDF). Engine makers who have initiated dual fuel methanol are MAN B\&W and Wartsila. Based on the low flashpoint characteristics and low cetane numbers, making dual fuel engine version is different from conventional engine [1], [6]. Besides engine makers, there are also several research initiatives to convert conventional diesel engines into dual fuel diesel fuelled methanol engines. Research such as Effship, SPIRETH, and PILOT Methanol. The results of some of these studies suggest that the methanol fuel applied to the vessel must have an installation added or modified. These include fuel tanks, piping systems, cooling systems, and bunkering systems [7].

The readiness of methanol fuel to be the main fuel or dual fuel still needs to be considered and developed. Especially in the retrofit process, conventional vessels need to be reviewed, either design (component or system layout) or safety. This is based on IGF Code regulation that prioritizes safety, the reliability of system that aimed at preventing fatal events [8].

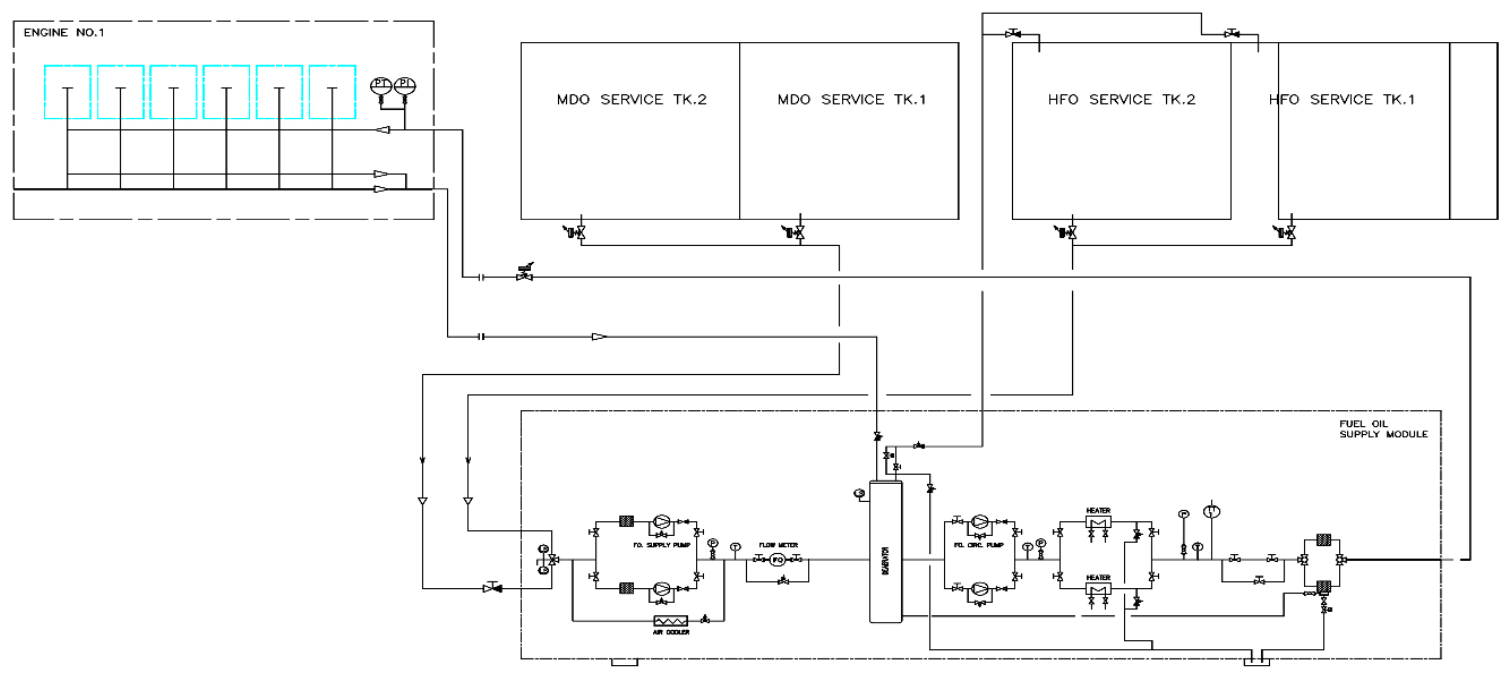

(a)

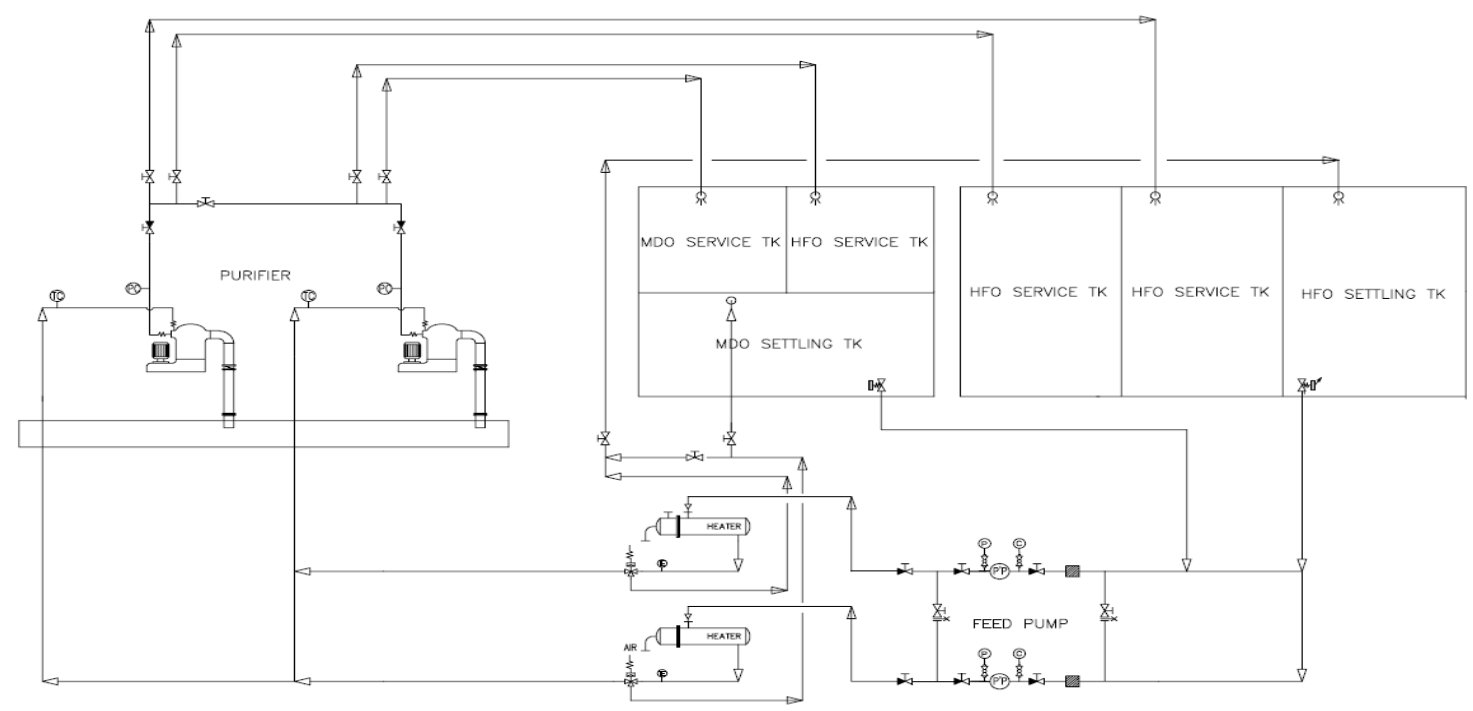

(b)

Figure 1: Conventional Fuel Oil System: (a) Supply System (b) Purifier System 


\section{Diesel Fuel \& Methanol Fuel}

\subsection{General}

The main engine is one of the machinery systems, the power source to ship propulsion system. Selection of diesel engines as the prime mover on the ship is seen from several aspects, such as ship type, size, speed and operational mode [9]. This paper, the methanol system will be applied, that previously used the conventional system. Between conventional systems and methanol, systems have a difference due to its characteristics. Furthermore, it will be explained requirements of components and systems that must be installed on a ship that modify the methanol system.

\subsection{Diesel Fuel Oil System (Heavy Fuel Oil/HFO)}

Heavy fuel oil (HFO) is a common fuel used by large ships and has a long mileage. This fuel is classified as lower level or so-called residue [10]. However, in ship operations, the fuel must be treated to maintain the viscosity of the fuel. Fig. 1 above, can be seen that HFO has several treatments before entering the engine. Including purifier and supply. Both systems, to maintain the fuel temperature and fuel viscosity. Fuel from storage tanks pumped towards settling tanks using circulating pumps, then filtered using purified before going to service tank. After in-service tank, the fuel pumped using feed pump (booster pump), which aims to adjust the pressure fuel that required by the engine. In this tank, fuel is heated to maintain the temperature and the viscosity. The last process supplies the fuel to the engine. Before entering the machine, first, heated in the heater and then pumped using a circulating pump to the engine.

\subsection{Diesel Methanol Dual Fuel System}

Different from HFO system, methanol fuel system requires additional components and systems. The modification of ship the system needs to redesign from adding components or systems and its laying according to the rules. Fig. 2 above, is the design of methanol fuel system that refers DNV-GL, as a requirement that must be installed on the ship, both new buildings and modified old buildings. This fuel distribution system starts from the storage tank located in the double bottom, then pumped towards the open deck to service tank. Furthermore, the fuel at the pump towards the LFSS or Fuel Supply System whose purpose is increasing the pressure according to injection pressure go into the engine. However, before entering the engine, fuel through in fuel valve train that serves as a pressure gauge, ensuring no leakage to the system and as an inerting gas and venting. The last process after the valve train unit is to enter the engine.

Some of the provisions required by DNV-GL [4] to methanol fuels application on ships, including:

a. Location of tanks

All tanks shall be inerted; Fuel tanks shall not be placed in the machinery spaces nor accommodation room; the redundancy of the fuel shall be provided for the vital and main system; the sufficient amount of fuel tank capacity should be provided for continuous rating operations of propulsion plant and normal operating load at sea of the generator plant for a period of not less than 8 hours; LFL tanks on open deck shall be protected against mechanical damage; open deck LFL tanks shall be surrounded by coamings

b. Piping

The fuel system of an LFL fuel shall be entirely isolated from all other piping systems on board; so that a leakage in the fuel supply system with following necessary safety actions does not lead to loss of propulsion, power generation or other; all piping shall be arranged for gas-freeing and inerting; the design pressure is the maximum working pressure to which system may be subjected; 
the design pressure for fuel piping is as a minimum to be taken as $10 \mathrm{bar}$; in cases where fuel piping must be led through accommodation spaces, the double walled fuel piping shall be led through a dedicated duct.

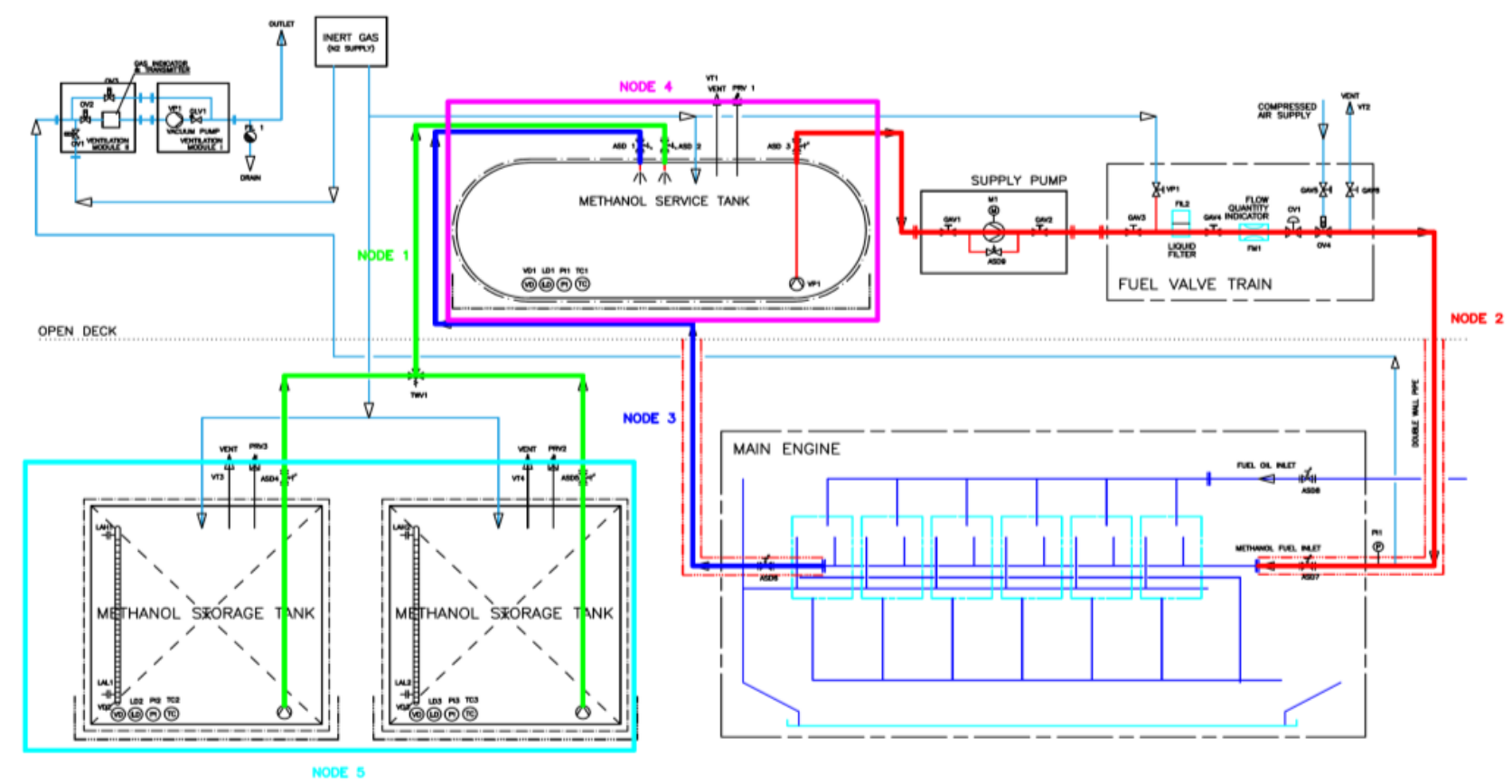

Figure 2. Methanol fuel system

c. Valves

LFL storage tank inlets and outlets shall be provided with remotely operated shut-off valves located as close to the tank as possible; The tank valve shall automatically cut off the LFL supply; Valves that are required to be operated during normal operation shall be remotely operated; Shutoff valve shall be situated outside the engine room; The LFL fuel supply to each consumer shall be provided with a remote shut-off valve; All automatic and remotely operated valves are to be provided with indications for open and closed valve positions at the location where the valves are remotely operated.

In general, the DNV-GL rules only address safety, how to prevent methanol fuel from leaking and impact both the system and the environment. However, it does not discuss technically to prevent the system running continuously. Therefore, hazop is used to identify the technical hazards of the system.

\section{Hazard \& Operability Study}

\subsection{General}

Performing Hazard \& Operability Study (HAZOP) consist of 2 (two) main purposes:

a. Identifying potential hazards in the system. The hazard which may occur regarding the operational. The process including find the possible causes and consequences to the operator or the system itself.

b. Find the potential operational disturbance and its possible escalation. Since the disturbance to the system also has potential to create a hazard to the personnel. 
The basis of HAZOP is a "guide word examination" which is a deliberate search for deviations from the design intent. To facilitate the examination, a system is divided into parts in such a way that the design intent for each part can be adequately defined [11]. The role of guide word is given systematical thinking guidance to focus the study and find the possible hazard in the operational, thereby maximizing the chances of study completeness. Basic guide words and their meanings are given in Table 1 [11].

Table 1: HAZOP Guide Words

\begin{tabular}{|c|l|}
\hline Guide Word & \multicolumn{1}{|c|}{ Meaning } \\
\hline NO OR NOT & Complete negation of the design intent \\
\hline MORE & Quantitative increase \\
\hline LESS & Quantitative decrease \\
\hline AS WELL AS & Qualitative modification/increase \\
\hline PART OF & Qualitative modification/decrease \\
\hline REVERSE & Logical opposite of the design intent \\
\hline OTHER THAN & Complete substitution \\
\hline
\end{tabular}

\subsection{Node Determination}

The process of HAZOP study was initially broken down according to the step and then by each action comprising the step. Each action was considered separately with the full list of guide words applied. Thus each action becomes a "node". It will ease the process of identifying deviation of corresponding components in the system. Node Determination in this case are:

a. Node - 1: Methanol pipeline transfer from a storage tank into service tank (open deck)

b. Node - 2: Methanol pipeline transfer from service tank into Main Engine

c. Node - 3: Methanol return line from Main Engine

d. Node - 4: Methanol service tank to supply daily consumption of Methanol

e. Node - 5: Methanol storage tanks

\section{Result}

Table 2: Result for HAZOP Node 1

\begin{tabular}{|c|c|c|c|c|c|c|c|}
\hline \multicolumn{2}{|c|}{ Study Title : } & \multicolumn{4}{|c|}{ Methanol Fuel System as Dual Fuel in Diesel Engine } & Sheet : & $1 / 1$ \\
\hline \multicolumn{2}{|c|}{ Node: } & \multicolumn{4}{|l|}{1} & Date : & $30 / 01 / 2018$ \\
\hline \multicolumn{2}{|c|}{ Design Intent : } & \multicolumn{4}{|c|}{$\begin{array}{l}\text { Methanol pipeline transfer from a storage tank into service tank (open } \\
\text { deck) }\end{array}$} & Meeting Date : & - \\
\hline \multicolumn{2}{|c|}{ Part Considered : } & \multicolumn{3}{|c|}{$\begin{array}{l}\text { - Storage Pump (SP) } \\
\text { - Automatic Shutdown Valve (ASD) }\end{array}$} & \multicolumn{3}{|c|}{ - Three Way Valve (TWV) } \\
\hline No & $\begin{array}{l}\text { Guide } \\
\text { Word }\end{array}$ & Deviation & $\begin{array}{l}\text { Possible } \\
\text { Causes }\end{array}$ & Consequences & Safeguard & Comments & Action Required \\
\hline \multicolumn{8}{|c|}{ Parameter : Flow } \\
\hline \multirow[t]{3}{*}{1} & No & No Flow & $\begin{array}{c}\text { SP not } \\
\text { working due to } \\
\text { failure }\end{array}$ & $\begin{array}{l}\text { Fuel cannot be } \\
\text { transferred to the } \\
\text { service tank, then it } \\
\text { will be empty }\end{array}$ & $\begin{array}{c}\text { No } \\
\text { corresponding } \\
\text { safeguards }\end{array}$ & $\begin{array}{c}\text { Ensured SP can } \\
\text { work optimally, } \\
\text { continuous power } \\
\text { should not operate } \\
\text { maximally } \\
\end{array}$ & $\begin{array}{l}\text { Adding a standby pump for optimal } \\
\text { distribution \& direct observation }\end{array}$ \\
\hline & & No Flow & \begin{tabular}{c|} 
ASD4 \& \\
ASD5 \\
inadvertently \\
close \\
\end{tabular} & $\begin{array}{l}\text { Pressure on pipes from } \\
\text { SP to ASD increases \& } \\
\text { SP potentially fails }\end{array}$ & $\begin{array}{l}\text { No } \\
\text { corresponding } \\
\text { safeguards }\end{array}$ & & Active observation of the ASD condition \\
\hline & & No Flow & $\begin{array}{c}\text { ASD2 } \\
\text { inadvertently } \\
\text { close }\end{array}$ & & $\begin{array}{c}\text { No } \\
\text { corresponding } \\
\text { safeguards }\end{array}$ & & \\
\hline
\end{tabular}




\begin{tabular}{|c|c|c|c|c|c|c|}
\hline & & No Flow & $\begin{array}{c}\text { TWV 1 } \\
\text { malfunction }\end{array}$ & $\begin{array}{l}\text { Misguidance of the } \\
\text { flow direction }\end{array}$ & $\begin{array}{c}\text { No } \\
\text { corresponding } \\
\text { safeguards }\end{array}$ & \\
\hline 2 & Less & Less Flow & $\begin{array}{l}\text { SP partially } \\
\text { performed }\end{array}$ & $\begin{array}{l}\text { Less flow rate into } \\
\text { service tank }\end{array}$ & $\begin{array}{c}\text { No } \\
\text { corresponding } \\
\text { safeguards }\end{array}$ & Constant monitoring of Pump \\
\hline 3 & More & More Flow & $\begin{array}{l}\text { SP produces } \\
\text { higher flow } \\
\text { rate }\end{array}$ & $\begin{array}{l}\text { High pressure in the } \\
\text { transfer system }\end{array}$ & & Constant monitoring of Pump \\
\hline
\end{tabular}

Table 3: Result for HAZOP Node 2

\begin{tabular}{|c|c|c|c|c|c|c|c|}
\hline \multicolumn{2}{|c|}{ Study Title : } & \multicolumn{4}{|c|}{ Methanol Fuel System as Dual Fuel in Diesel Engine } & Sheet : & $1 / 1$ \\
\hline \multicolumn{2}{|c|}{ Node: } & \multicolumn{4}{|l|}{2} & Date : & $30 / 01 / 2018$ \\
\hline \multicolumn{2}{|c|}{ Design Intent : } & \multicolumn{4}{|c|}{ Methanol pipeline transfer from service tank into Main Engine } & Meeting Date: & - \\
\hline \multicolumn{2}{|c|}{ Part Considered : } & \multicolumn{3}{|c|}{$\begin{array}{l}\text { - Supply Pump } \\
\text { - Fuel valve train }\end{array}$} & \multirow[b]{2}{*}{ Safeguard } & & \\
\hline No & $\begin{array}{l}\text { Guide } \\
\text { Word }\end{array}$ & Deviation & Possible Causes & Consequences & & Comments & $\begin{array}{l}\text { Action } \\
\text { Required }\end{array}$ \\
\hline \multicolumn{8}{|c|}{ Parameter : Flow } \\
\hline \multirow[t]{2}{*}{1} & No & No Flow & Main supply pump M1 malfunction & $\begin{array}{l}\text { Methanol can not transfer to fuel } \\
\text { valve train and main engine }\end{array}$ & $\begin{array}{l}\text { ASD9 and the } \\
\text { bypass line, flow } \\
\text { quantity indicator }\end{array}$ & & \\
\hline & & No Flow & $\begin{array}{l}\text { ASD3 and/or GAV1 and/or GAV2 and/o } \\
\text { GAV3 and/or GAV4 and/or CV1 and/or } \\
\text { OV4 and/or ASD7 failed, and/or FIL2 } \\
\text { blocked }\end{array}$ & $\begin{array}{l}\text { Methanol can not deliver to the } \\
\text { main engine }\end{array}$ & $\begin{array}{l}\text { flow quantity } \\
\text { indicator, PI1 }\end{array}$ & & \\
\hline \multirow[t]{2}{*}{2} & Less & Less Flow & $\begin{array}{l}\text { Main supply pump M1 perform not } \\
\text { satisfactory well }\end{array}$ & $\begin{array}{l}\text { Less flow rate into main engine } \\
\text { requirement lead to main engine } \\
\text { encounter performance } \\
\text { degradation }\end{array}$ & $\begin{array}{l}\text { Flow quantity } \\
\text { indicator, } \mathrm{P} 1\end{array}$ & & \\
\hline & & Less Flow & $\begin{array}{l}\text { FIL2 and/or CV1 encounter sufficient } \\
\text { blockage to reduce the flow rate }\end{array}$ & $\begin{array}{l}\text { Less flow rate into main engine } \\
\text { requirement lead to main engine } \\
\text { encounter performance } \\
\text { degradation }\end{array}$ & $\begin{array}{l}\text { Flow quantity } \\
\text { indicator, } \mathrm{P} 1\end{array}$ & & \\
\hline 3 & More & More Flow & $\begin{array}{l}\text { Main supply pump M1 deliver too much } \\
\text { pressure }\end{array}$ & $\begin{array}{l}\text { Engine receive higher flow rate } \\
\text { than the designated flowrate }\end{array}$ & $\begin{array}{l}\text { Flow quantity } \\
\text { indicator, P1 }\end{array}$ & & \\
\hline
\end{tabular}

Table 4: Result for HAZOP Node 3

\begin{tabular}{|c|c|c|c|c|c|c|c|}
\hline \multicolumn{2}{|c|}{ Study Title : } & \multicolumn{4}{|c|}{ Methanol Fuel System as Dual Fuel in Diesel Engine } & Sheet : & $1 / 1$ \\
\hline \multicolumn{2}{|c|}{ Node : } & \multicolumn{4}{|l|}{3} & Date: & $30 / 01 / 2018$ \\
\hline \multicolumn{2}{|c|}{ Design Intent : } & \multicolumn{4}{|c|}{ Methanol return line from Main Engine } & Meeting Date: & - \\
\hline \multicolumn{2}{|c|}{ Part Considered : } & \multicolumn{3}{|l|}{-ASD6 } & & & \\
\hline No & $\begin{array}{l}\text { Guide } \\
\text { Word }\end{array}$ & Deviation & Possible Causes & Consequences & Safeguard & Comments & $\begin{array}{l}\text { Action } \\
\text { Required }\end{array}$ \\
\hline \multicolumn{8}{|c|}{ Parameter : Flow } \\
\hline 1 & No & No Flow & $\begin{array}{l}\text { ASD6 and/or ASD1 } \\
\text { malfunction }\end{array}$ & $\begin{array}{l}\text { No fuel return to service } \\
\text { tank }\end{array}$ & $\begin{array}{l}\text { No corresponding } \\
\text { safeguards }\end{array}$ & $\begin{array}{l}\text { At adequate amount of fuel, if there is } \\
\text { no returned fuel as long as it as the } \\
\text { engine requirement, it considered } \\
\text { normal. }\end{array}$ & \\
\hline 2 & Reverse & $\begin{array}{l}\text { Reverse } \\
\text { Flow }\end{array}$ & $\begin{array}{l}\text { ASD6 closed and/or } \\
\text { backpressure in the } \\
\text { system }\end{array}$ & $\begin{array}{l}\text { Main engine encounter } \\
\text { overfilling of methanol } \\
\text { fuel }\end{array}$ & $\begin{array}{l}\text { Consideration of } \\
\text { engine maker }\end{array}$ & & \\
\hline
\end{tabular}

Table 5: Result for HAZOP Node 4

\begin{tabular}{|c|c|c|c|c|c|c|c|}
\hline \multicolumn{2}{|c|}{ Study Title : } & \multicolumn{4}{|c|}{ Methanol Fuel System as Dual Fuel in Diesel Engine } & Sheet : & $1 / 1$ \\
\hline \multicolumn{2}{|c|}{ Node : } & \multicolumn{4}{|l|}{4} & Date: & $30 / 01 / 2018$ \\
\hline \multicolumn{2}{|c|}{ Design Intent : } & \multicolumn{4}{|c|}{ Methanol service tank to supply daily consumption of Methanol } & Meeting Date : & - \\
\hline \multicolumn{2}{|c|}{ Part Considered : } & \multicolumn{3}{|c|}{-Methanol service tank and its equipment } & & & \\
\hline No & $\begin{array}{l}\text { Guide } \\
\text { Word }\end{array}$ & Deviation & Possible Causes & Consequences & Safeguard & Comments & $\begin{array}{l}\text { Action } \\
\text { Required }\end{array}$ \\
\hline
\end{tabular}




\begin{tabular}{|c|l|l|l|l|l|l|}
\hline 1 & No & No Fluids & $\begin{array}{l}\text { Filing system from storage } \\
\text { tank fail }\end{array}$ & $\begin{array}{l}\text { The system cannot supply Main } \\
\text { Engine with methanol }\end{array}$ & LD1 \\
\hline 2 & More & More Pressure & $\begin{array}{l}\text { High evaporation of } \\
\text { methanol fuel }\end{array}$ & $\begin{array}{l}\text { Tanks overpressure and lead to } \\
\text { leakage }\end{array}$ & $\begin{array}{l}\text { Vent V1, PRV1, } \\
\text { PI1 }\end{array}$ & $\begin{array}{l}\text { Vent V1, PRV1, } \\
\text { PI1 }\end{array}$ \\
\hline 3 & More & $\begin{array}{l}\text { More } \\
\text { Temperature }\end{array}$ & $\begin{array}{l}\text { Create high pressure on service tank } \\
\text { to weather }\end{array}$ & \\
\hline
\end{tabular}

Table 6: Result for HAZOP Node 5

\begin{tabular}{|c|c|c|c|c|c|c|c|}
\hline \multicolumn{2}{|c|}{ Study Title : } & \multicolumn{4}{|c|}{ Methanol Fuel System as Dual Fuel in Diesel Engine } & Sheet : & $1 / 1$ \\
\hline \multicolumn{2}{|c|}{ Node : } & \multicolumn{4}{|l|}{5} & Date: & $30 / 01 / 2018$ \\
\hline \multicolumn{2}{|c|}{ Design Intent : } & \multicolumn{4}{|c|}{ Methanol storage tanks } & Meeting Date : & - \\
\hline \multicolumn{2}{|c|}{ Part Considered : } & \multicolumn{3}{|c|}{-Methanol storage tank and its equipment } & & & \\
\hline No & $\begin{array}{l}\text { Guide } \\
\text { Word }\end{array}$ & Deviation & Possible Causes & Consequences & Safeguard & Comments & Action Required \\
\hline \multicolumn{8}{|c|}{ Parameter : Fluids, Pressure,, Temperature } \\
\hline 1 & More & More Fluids & $\begin{array}{l}\text { Overfilling during } \\
\text { bunkering }\end{array}$ & Storage tanks overfill & $\begin{array}{l}\text { LAH1 and } \\
\text { LAH2 }\end{array}$ & & \\
\hline 2 & More & More Pressure & $\begin{array}{l}\text { High evaporation of } \\
\text { methanol fuel }\end{array}$ & $\begin{array}{l}\text { Tanks overpressure and lead to } \\
\text { leakage }\end{array}$ & VD1, VD2 & $\begin{array}{l}\text { Pressure indicator } \\
\text { suggested being added }\end{array}$ & \\
\hline 3 & More & $\begin{array}{l}\text { More } \\
\text { Temperature } \\
\end{array}$ & $\begin{array}{l}\text { High ambient } \\
\text { temperature }\end{array}$ & $\begin{array}{l}\text { The high evaporation rate of the } \\
\text { methanol possibly ignited the fuel }\end{array}$ & Inert gas system & & \\
\hline 4 & Less & Fewer Fluids & $\begin{array}{l}\text { The fluids are running } \\
\text { low }\end{array}$ & Service tank is not sufficiently filled & $\begin{array}{l}\text { LAL1 and } \\
\text { LAL2 }\end{array}$ & & $\begin{array}{l}\text { The changeover to } \\
\text { another tank }\end{array}$ \\
\hline
\end{tabular}

\section{Conclusion}

Today, the great majority of world trade takes place by sea. In this context, the APBS has a very important role. Tanjung Perak Port is one of the busiest main ports in Indonesia. Currently the shipping route to Tanjung Perak Port has two paths namely the Surabaya western access channel (APBS) and the Surabaya Eastern access channel (APTS). The marine traffic is increasing annually has caused marine safety problems. From the results of the analysis conducted are as follows:

1. Based on data of ship visits at Tanjung Perak Port, in the period of 2011 to 2016 there was an increase of GT vessels averaging $2.05 \%$, while ship units decreased by an average of $2.33 \%$.

2. The number of ship accident events in APBS before and after the revitalization is quite high. This is seen from the total incidence of accidents from 2010 to 2016 as many as 122 cases. Before the revitalization of 2010 until 2014 there were 100 accidents or an average of 20 cases of accidents per year. After the revitalization of 2015 to 2016 there are 22 cases or an average of 11 cases per year. So there is a decrease in accident cases between before and after the revitalization is about $100 \%$.

3. Of the five types of accidents occurring in the APBS after the revitalization is the impact of 8 cases or $36.5 \%$, ship fire 7 cases or $31.8 \%$, sink and grounding each of 3 cases or $13.6 \%$ and others as much as 1 case or $4.5 \%$.

4. The number of ship accident events APBS is quite high. This is seen from the total incidence of accidents during from 2010 to 2016 as many as 122 cases. After the calculation, the five types of accidents that occurred in the four types of accidents that have a high risk of ship collision, followed by fire, others and ship sink.

5. The causes of accidents before the revitalization from 2013 until the year 2014 as many as 40 cases of accidents, human factors are as many as 24 cases or by $60 \%$, the cause of technical factor accidents as many as 12 cases or by $30 \%$ and for natural factors are as many as 4 cases or by $10 \%$. Meanwhile, after revitalization from 2015 until 2016, there were 18 cases, with human factor causing 15 cases or $83.3 \%$, technical causes as many as 3 cases or $16.7 \%$ and natural factors as the cause of the accident did not exist. 
6. The cause of accidents for human factors is a major factor in the occurrence of accidents both before and after revitalization. Human factors as the cause of accidents experienced a significant increase of $20 \%$ from before and after revitalization, while for other factors of accidents, such as technical factors and natural factors decreased significantly.

7. When the risk of accidents can be reduced. In this case, any risk from the cause of accidents in APBS can be reduced by $10-40 \%$ and the benefits of accident risk reduction can save expenses by $30-50 \%$.

\section{References}

[1] K. Andersson and M. Márquez Salazar, "Methanol as a Marine Fuel," p. 46, 2015.

[2] Ø. Buhaug et al., “Second IMO GHG Study 2009,” London, 2009.

[3] K. Andersson and C. M. Salazar, "Methanol as a marine fuel report," 2015.

[4] E. Hughes, S. Laselle, H. Hustad, J. Vedeler, and H. Abusdal, "Methanol as marine fuel : Environmental benefits, technology readiness, and economic feasibility." DNV-GL Maritime Environmental Advisory, pp. 1-48, 2016.

[5] A. Lundgren and A. Wachsmann, "The potential of methanol as a competitive marine fuel," 2014.

[6] MAN Diesel \& Turbo, "Using Methanol Fuel in the MAN B\&W ME-LGI Series, " Denmark, 2014.

[7] K. Andersson and M. Márquez Salazar, "Methanol as a Marine Fuel," no. January, p. 46, 2015.

[8] International Maritime Organization (IMO), "MSC.285 (86) Interim Guidelines on Safety NG Installation in Ships, ” 2009.

[9] R. L. Harrington, Book of Marine Engineering. Suite1369, New York: The Society of Naval Architect and Marine Engineers, 1971.

[10]D. Woodyard, Book of Marine Diesel Engine. Linacre House, Jordan Hill, Oxford OX2 8DP: Elsevier Ltd, 2004.

[11]A. Musyafa and H. Adiyagsa, "Hazard and Operability study in Boiler System of The Steam Power Plant," IEESE Int. J. Sci. Technol., vol. 1, no. 3, pp. 1-10, 2012. 